\title{
An Old Method Turnbull Cutait; Using for Middle and Distal Rectal Cancer Surgery without lleostomy. Oncological and Fuctional Late Outcomes
}

\author{
Eski Bir Yöntem Turnbull Cutait; İleostomi Olmadan Orta ve Distal Rektal \\ Kanser Cerrahisinde Kullanılması. Onkolojik ve Fonksiyonel Geç Sonuçlar
}

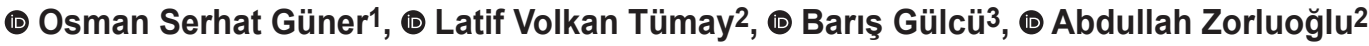 \\ ${ }^{1}$ Acıbadem Bodrum Hospital, Clinic of Surgery, Muğla, Turkey \\ ${ }^{2}$ Acıbadem Bursa Hospital, Clinic of Surgery, Bursa, Turkey \\ 3 Medicana Bursa Hospital, Clinic of Surgery, Bursa, Turkey
}

\section{HIIIIII ABSTRACT}

Aim: Anastomotic leak after sphincter-preserving surgery for rectal cancer may be a disaster scenario. To reduce the severity of anastomotic leakage a prophylactic diverting ileostomy is usually used for mid or distal rectal cancer patients. However, Turnbull Cutait Abdominoperineal Pull-Through Procedure ( $\mathrm{T}-\mathrm{C}$ ) with low anastomotic leakage rates is an old method that is applied without diverting ileostomy. We aimed to evaluate the long-term functional and oncological results of the T-C procedure performed in patients with rectum cancer refusing diverting ileostomy.

Method: Patients with middle or low rectal cancer who underwent T-C from March 2006 to December 2012 retrospectively reviewed for late results. Demographics, oncologic characteristics, postoperative complications, fuctional outcomes and overall survival (OS) time were evaluated. For functional results, Wexner Continence Grading scale scores, bladder functions, sexual functions, and SF-12 questionnaires were performed in all patients. In addition, anal manometry and defecography were performed in 7 patients.

Results: Thirteen patients (6 men) median age 55 (range 44-82) years with rectal tumors at a median distance of $4 \mathrm{~cm}$ (range 1.5-7) from the anal verge underwent T-C. Mean follow-up was 101.2 (standard deviation 42.7) mounts. The 5-year OS rates was $85 \%$. Postoperative morbidity rate is $23 \%$ (3 patients). However, pelvic sepsis, anastomotic leak and perianal fistula were not seen. Functional results were good in $90 \%$ of patients at the end of the second year. Due to ongoing fragmentation and evacuation problems, 2 patients underwent permanent stoma.

Conclusion: T-C with reasonable oncologic and functional results can be safely used sphincter-preserving procedure to treat patients with middle and distal rectal cancer without creation of diverting ileostomy.

Keywords: Late results, turnbull-cutait, abdominoperineal pull-through procedure, without diverting ileostomy

\section{|||||||||| ÖZ}

Amaç: Rektum kanserinde sfinkter koruyucu cerrahi sonrası anastomoz kaçağı gelişmesi felaket senaryosuna neden olabilir. Bu komplikasyonun şiddetini azaltmak için orta ve distal yerleșimli rektum tümörü olgularında genellikle koruyucu ileostomi açılmaktadır. Turnbull-Cutait abdominoperineal pull-through prosedürü (T-C) ileostomi açılmadan uygulanabilen düşük anastomoz kaçak oranlarına sahip eski bir yöntemdir. İleostomi açılmasını kabul etmeyen rektum kanseri olgularında uyguladığımız T-C prosedürünün uzun dönem onkolojik ve fonksiyonel sonuçlarını incelemeyi amaçladık.

Yöntem: Kliniğimizde Mart 2006-Aralık 2012 tarihleri arasında orta veya distal yerleşimli rektum kanseri nedeni ile T-C prosedürü uygulanan olgular geriye dönük olarak incelendi. Demografik ve onkolojik özellikler, postoperatif komplikasyonlar, fonksiyonel sonuçlar ve genel sağkalım süreleri değerlendirildi. Fonksiyonel sonuçlar; Wexner Continence Grading skala skoru, mesane, cinsel fonksiyonlar ve hayat kalitesi (SF-12) anketleri ile değerlendirildi. Ayrıca 7 hastaya anal manometri ve defakografi uygulandı.

Bulgular: Toplam on üç hastaya ( 6 erkek ) T-C uygulandı. Olguların ortalama yaşı median 55 (44-82) yıl, tümörün anal vergeden uzaklığı ortalama $4(1,5-7) \mathrm{cm}$ idi. Olgular ortalama $101,2 \pm 42,7$ ay takip edildi. Beş yıllık genel sağkalım oranı $\% 85$ olarak saptandı. Postoperatif morbidite oranı

Address for Correspondence/Yazışma Adresi: Osman Serhat Güner MD,

Acıbadem Bodrum Hospital, Clinic of Surgery, Muğla, Turkey

Phone: +90 5322216142 E-mail: serhatguner@yahoo.com ORCID ID: orcid.org/0000-0002-9715-2435

Received/Geliş Tarihi: 10.01.2020 Accepted/Kabul Tarihi: 16.02.2020

${ }^{\odot}$ Copyright 2020 by Turkish Society of Colon and Rectal Surgery

Turkish Journal of Colorectal Disease published by Galenos Publishing House. 
\%23’tür (3 hasta). Pelvik sepsis, anastomoz kaçağı ve perianal fistül görülmedi. Postoperatif iki yıl sonunda hastaların \%90'ında fonksiyonel sonuçların iyi olduğu saptandı. Devam eden fragmantasyon ve boşaltım problemleri nedeniyle 2 hastaya kalıcı stoma uygulandı.

Sonuç: T-C prosedürü, orta ve distal yerleşimli rektum tümörlerinin sfinkter koruyucu cerrahi tedavisinde koruyucu ileostomi açılmadan uygulanabilen, kabul edilebilir onkolojik ve fonksiyonel sonuçları ile güvenle kullanılabilen bir tekniktir.

Anahtar Kelimeler: Geç sonuçlar, turnbull-cutait, abdominoperineal pull-through, koruyucu ileostomisiz

\section{Introduction}

Anastomotic leak can be a catastrophic complication following sphinctersparingsurgery for rectal cancer especially if very low anterior resection and colo-anal anastomosis is performed. A prophylactic diverting ileostomy is used up to $100 \%$ in middle and distal rectal cancer patients receiving neoadjuvant chemo radiotherapy (CRT) in order to prevent or reduce the severity of anastomotic leakage, especially when sphincter-preserving surgery is performed.

In early 1950's Turnbull in Cleveland Clinic and Cutait in Brazil introduced two staged transanal anastomosis technique simultaneously. Their indications included midrectal cancer, and children with Hirsprung's disease. They both described the operative technique as a two stage pull through procedure. First stage includes resection of the affected segment and pull through of the remaining distal colon through anus. On second stage after several days under the protection of adherencies and scar tissue coloanal anastomosis is performed avoiding stoma procedure. ${ }^{1,2}$ This procedure was largely abandoned due to the introduction of stapling anastomotic devices. Later after the introduction of neoadjuvant theraphies it was reintroduced by some surgeons. It is suggested that this operation can be used on patients who do not want permanent or temporary ileostomy. Potential candidates for Turnbull-Cutait (T-C) procedure; are reoperated, who have irradiated pelvis with chronic inflammation or infection due to persistant sepsis and as a salvage procedure for complex anorectal conditions as an alternative to permanent stoma creation. ${ }^{3,4,5}$

In this study we evaluated the long term outcomes of patients who had T-C procedure due to mid or distal rectal cancer without diverting ileostomy.

\section{Materials and Methods}

Thirteen patients who underwent T-C after total mesorectal excision (TME) for middle and low rectal cancer between March 2006 and December 2012 were retrospectively analyzed using the patient database and most recent survival status was further confirmed by phone contact with patients or relatives.

Patients with histopathologic adenocarcinoma who had rectal carcinoma of the middle and distal location, who did not accept permanent stoma opening when not necessary, were included in the study. Patients with histopathology other than adenocarcinoma, patients with distant metastasis at admission and patients with low anal sphincter tone on digital examination and who identified incontinence at admission were excluded from the study.

The following variables were evaluated in the study: patient demographics and characteristics, oncological characteristics, early and late postoperative complications, follow-up results, and overall survival (OS) time. Early postoperative complication was defined as the occurrence of complications within 30 days after surgery. Late complication was defined as complications that developed after the first postoperative month. OS was defined as the time period between surgery and death.

Neoadjuvant therapy was recommended to clinical T3-T4 and/or $\mathrm{N}(+)$ patients. Two patients received preoperative radiotherapy (mean: 45Gy), eight patients received preoperative CRT (mean 45 Gy, 5-fluorouracil). Three patients did not receive neoadjuvant treatment. Neoadjuvan theraphy was not recommended in two patients with clinical T1-T2, and one of the T3 patients did not accept neoadjuvan theraphy. The mean time from radiotherapy to surgery was eight weeks (range: 6 to 10 weeks).

The study protocol was approved by the local ethics committee of our institution (date, November 21, 2019; no. ATADEK-2019-18/16). The study was conducted in accordance with the principles of the Declaration of Helsinki. A written informed consent concerning the surgical risks was obtained from all patients. The preoperative assessment included a digital rectal examination, a colonoscopy with biopsy, a thoracic, abdominal, and pelvic computed tomography scan, and pelvic magnetic resonance imaging. The patients were classified according to the $7^{\text {th }}$ edition American Joint Committee on Cancer classification system. A standardized follow-up was completed at one month after surgery, then every three months during the first two years, and every six months in the third through the fifth year.

The quality of life was evaluated using the Short-Form 12 Health Survey (Ware, Kosinski, \& Keller, 1996) Questionnaire $^{6}$ (Figure 1). Faecal continence was evaluated using the Wexner continence score ${ }^{7}$, which ranges from 0 (normal continence) to 20 (maximum incontinence) (Figure 2) Wexner scores were considered to be very good 


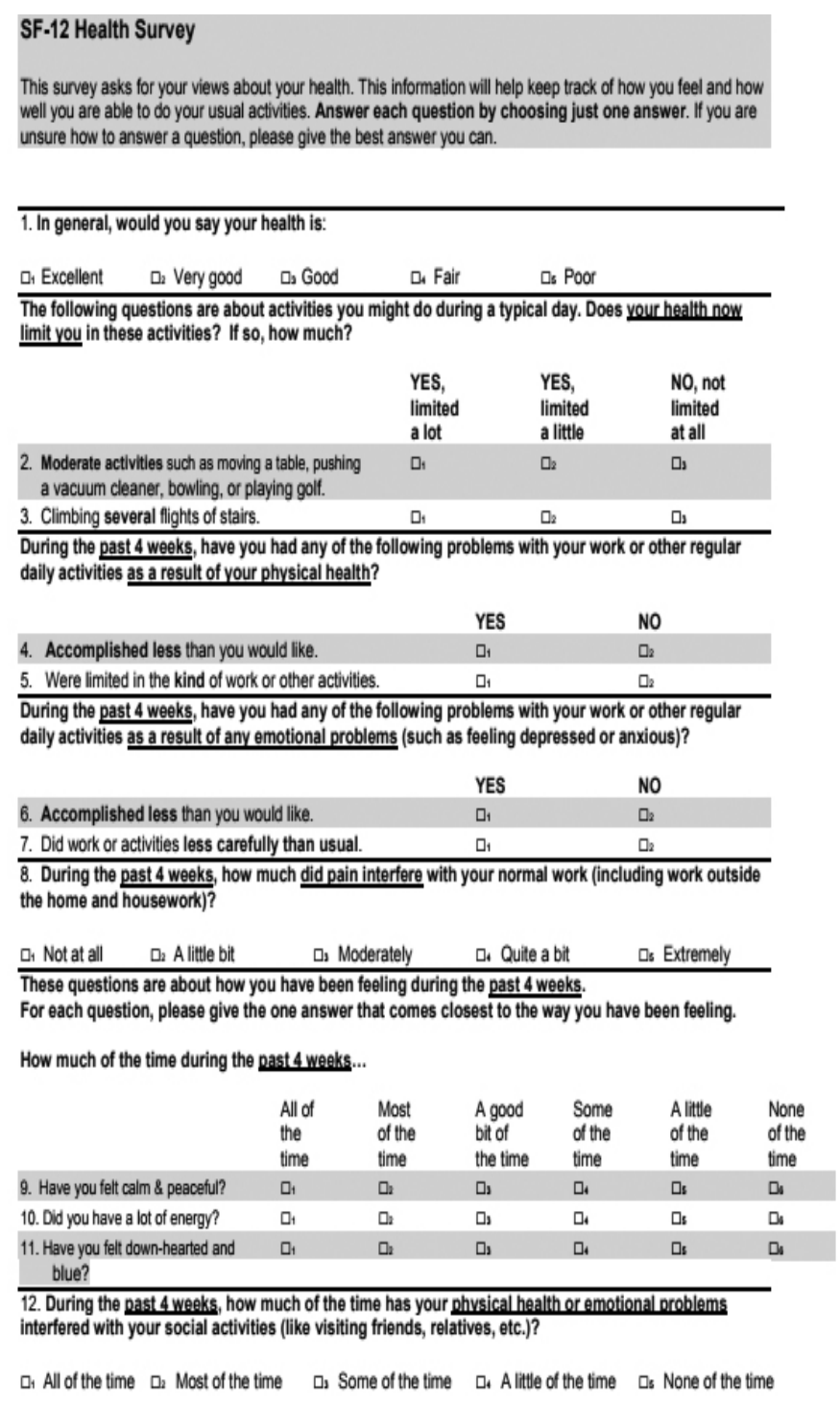

Figure 1. Ware J Jr, Kosinski M, Keller SD. A 12-Item Short-Form Health Survey: construction of scales and preliminary tests of reliability and validity. Med Care 1996 Mar;34:220-233.

\begin{tabular}{lccccc}
\multirow{2}{*}{$\begin{array}{c}\text { Type of } \\
\text { Incontinence }\end{array}$} & \multicolumn{5}{c}{ Frequency } \\
\cline { 2 - 6 } & \multicolumn{4}{c}{ Never Rarely $\begin{array}{c}\text { Some- } \\
\text { times }\end{array}$} & Usually Always \\
\hline Solid & 0 & 1 & 2 & 3 & 4 \\
Liquid & 0 & 1 & 2 & 3 & 4 \\
Gas & 0 & 1 & 2 & 3 & 4 \\
Wears pad & 0 & 1 & 2 & 3 & 4 \\
Lifestyle alteration & 0 & 1 & 2 & 3 & 4 \\
\hline
\end{tabular}

$0=$ perfect.

$20=$ complete incontinence.

Never $=0$ (never).

Rarely $=<1 /$ month.

Sometimes $=<1 /$ week, $\geq 1 /$ month.

Usually $=<1 /$ day, $\geq 1 /$ week.

Always $=\geq 1 /$ day.

Figure 2. Jorge JM, Wexner SD. Etiology and management of fecal incontinence. Dis Colon Rectum 1993;36:77-97. between 0-5, good between 5-10 and bad over 10. A bladder questionnaire and a sexual function questionnaire specifc to each sex. Wexner score, SF-12, bladder and sexual function questions were repeated at 6 months, 1 and 2 years. Anal manometry and defecography were performed in 7 patients in the $6^{\text {th }}$ postoperative month.

\section{Surgical Technique}

The surgical procedure of TME followed by T-C involved two stages.

\section{First Stage}

The patients were placed in the Lloyd-Davis position, and an abdominoperineal approach was used. Following an abdominal incision, conventional very low anterior resection with TME was carried out in accordance with the oncological principles of no-touch technique, high vascular ligation, and nerve sparing. After complete splenic flexure mobilization, the inferior mesenteric vein was sectioned close to the ligament of Treitz. The inferior mesenteric artery was isolated, ligated, and divided $1-\mathrm{cm}$ to the aorta, and dissection of the colon and sigmoid colon was finally performed along the holy plane, until the pelvic floor was reached and isolation of the distal rectal resection line (tumor free zone) was obtained. Pelvic dissection was performed down to the level of the levator ani musculature. In the perineal phase, a LoneStar retractor (Lone Star Medical Products, Stafford, TX, USA) was inserted to the anus and the internal muscle (circular and longitudinal) was cut through the dentate line and $1 \mathrm{~cm}$ above using the monopolar cautery and the intersphincteric plane was reached. The cranial lumen was closed through the purse string sutures and dissection was continued posteriorly. Then, the pelvic dissection plane was reached through abdomen. Before pulling the colon through the anal canal, four 3/0 polyglactic acid sutures were placed at the cardinal points of the anal canal, as high as possible, by pinching the upper edge of internal sphincter, thereby, avoiding fullthickness damage to the muscle. The rectum and sigmoid colon were, then, pulled through the anal canal and cut at the level of the ligation of the left colic artery. A colonic segment of about $10 \mathrm{~cm}$ was left outside. Finally, the colonic exteriorized segment was fixed to the perianal skin with 4-6 sutures and was wrapped in wet gauze. The colonic stump viability was checked once daily (Figure 3 ).

\section{Second Stage}

The second surgical stage was performed between postoperative days 5 and 7. During the waiting period, the patients were fasted and total parenteral nutrition was given $2000 \mathrm{kcal} /$ day. During this period, movements that caused pressure in the colonic exteroised segment were restricted (they were ordered to sleep in lateral decubitus position and while lying supine both legs in abduction, without 
mobilization restriction). The colonic stump viability was checked once a daily. The second procedure was performed under sedation and epidural anesthesia.

Patients were placed in the lithotomy position. No retractors were needed, and the adhesions between the anal canal and colon were preserved. After tying off the mesocolon at the level of the anal verge, the exteriorized segment was cut with

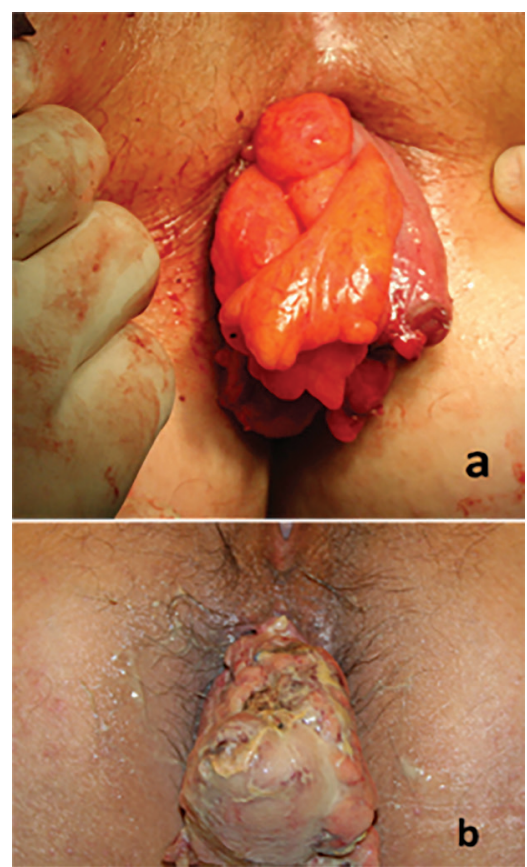

Figure 3. View of the exteriorized colon segment. a) intraoperative view of the colonic stump at the end of the first stage, $\mathbf{b}$ ) post-operative $6^{\text {th }}$ day view of the colonic stump

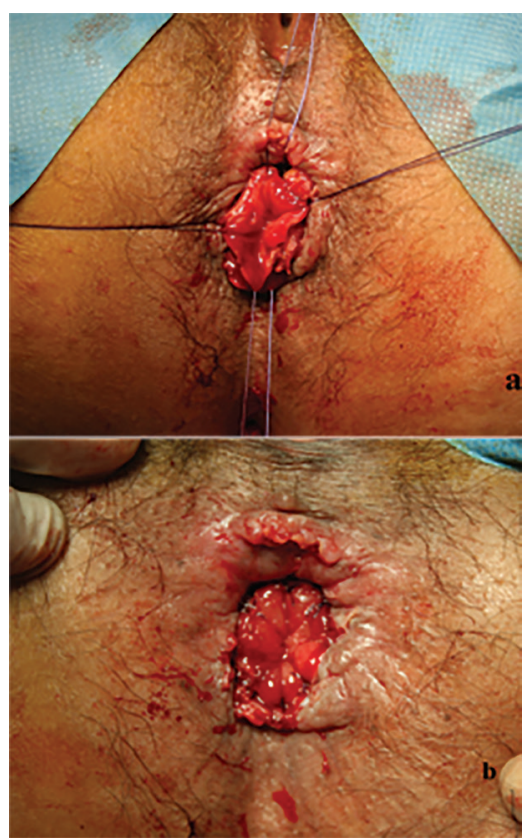

Figure 4. View of delayed coloanal anastomosis (CAA). a) During CAA, b) After the completion of CAA

CAA: Coloanal anastomosis cautery; a hand-sewn, colo-anal anastomosis was performed using 8-12 interrupted sutures at the dentate line level. The lumen was, then, checked with anoscopy (Figure 4).

\section{Statistical Analysis}

Statistical analysis was performed using the Statistical Package for Social Sciences (SPSS) for Windows version 21.0 (IBM Corp., Armonk, NY, USA). The data were presented in mean \pm standard deviation $(\mathrm{SD})$ or median (minimummaximum) values. Qualitative variables were expressed in number and percentage. Mean OS was calculated using Kaplan-Meier test.

\section{Results}

A total of 13 patients, six were males with a median age of 55 years (range: 44 to 82 years) and mean body mass index (BMI) of $29.19 \pm 6.3 \mathrm{~kg} / \mathrm{m}^{2}$. All patients underwent T-C. The median distance between the inferior margin of the tumor and the anal verge was $4 \mathrm{~cm}$ (range: $1.5-7 \mathrm{~cm}$ ). Histopathological findings are shown in Table 1. Using the AJCC staging, two patients were classified as Stage I, four as Stage IIA, four as Stage IIIB, and three as Stage IIIC. The median interval between first and second surgical procedure was 8 days (range 6-10) and the median length of hospital stay was nine days (range: 7 to 13 days).

The rate of postoperative morbidity was 23\% ( $n=3)$. Among the early surgical morbidities, one patient was diagnosed with pelvic abscess, one with hemorrhage, and one with necrosis about 20\% of the exteriorized colonic segment after the first stage of the procedure. However, no pelvic sepsis, anastomotic leak, or perianal fistula were seen. Late morbidity was observed in three patients. Two patients (15.3\%) had requiring permanent colostomy and one (7.7\%) had anastomotic stricture requiring balloon dilatation.

Table 1. Histopathological findings

$\begin{array}{ll}\text { Histopathological type } & \mathbf{n}=13 \\ \begin{array}{l}\text { Adenocarsinom } \\ \text { Surgical marjin }\end{array} & 13(100 \%) \\ \text { Negative } & 13(100 \%) \\ \text { Differentiation } & \\ \text { Poor } & 1(7.7 \%) \\ \text { Moderate } & 8(61.6 \%) \\ \text { Well } & 4(30.7 \%) \\ \text { Perineural invasion } & 5(38.4 \%) \\ \text { Venous invasion } & 2(15.4 \%) \\ \text { Lymphatic invasion } & 1(7.7 \%) \\ \text { Extranodal involvement } & 4(30.7 \%)\end{array}$




\section{Oncological Outcomes}

The mean follow-up was 101.2 [standard deviation (SD) 42.7] months. Three patients which was Stage III C, one patient which was Stage III B have died because of metastatic disease in follow up.

The OS was at one year $100 \%$ three years $85 \%$ and at five years $85 \%$ (Figure 5). No local recurrence was observed.

\section{Functional Outcomes}

Table 2 shows functional outcomes. The results of anal manometry (Table 3) and defecography (Table 4) are as in the tables. Two patients (15.3\%) had severe rectal evacuation problem requiring permanent colostomy and one $(7.7 \%)$ had anastomotic stricture requiring balloon dilatation. After 6 months 30\% of the patients had frequent

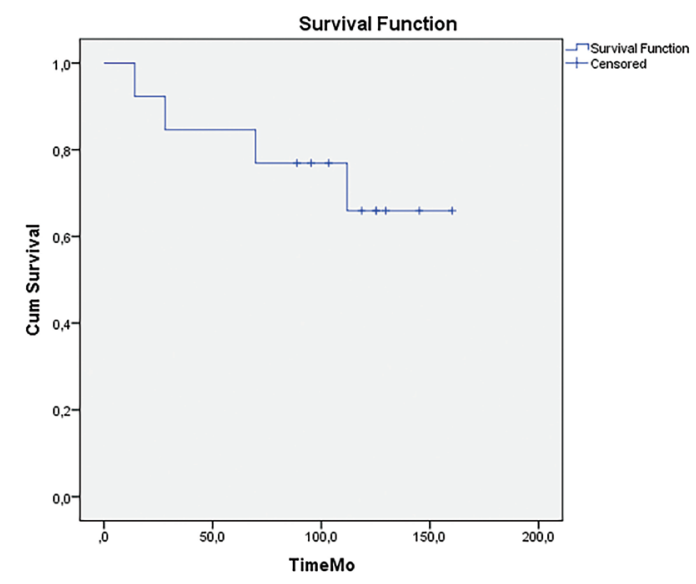

Figure 5. Kaplan-Meier survival analysis

Table 2. Functional outcomes

$\begin{array}{llll}\text { Functions } & \begin{array}{l}\text { T-C p.o } 6^{\text {th }} \text { months } \\ (\mathbf{n}=13)\end{array} & \begin{array}{l}\text { T-C p.o } 1^{\text {st }} \text { year } \\ (\mathbf{n}=13)\end{array} & \begin{array}{l}\text { T-C p.o } 2^{\text {nd }} \text { year } \\ (\mathbf{n}=13)\end{array} \\ \begin{array}{l}\text { Bowel function } \\ \text { Wexner continence score* }\end{array} & 9.3(2.52) & 7.3(2.32) \\ \text { Bladder function } & 11.5(2.70) & 10) \\ \text { Urinary incontinence } & 0(0 \%) & 0(0 \%) & 0(0 \%) \\ \text { Poor stream } & 2(15.4 \%) & 1(7.7 \%) & 1(7.7 \%) \\ \text { Nocturnal micturition } & 3(23.1 \%) & 2(15.4 \%) & 2(15.4 \%) \\ \text { Sexual function } & 6(46.1 \%) & 7(53.8 \%) & 9(69.3 \%) \\ \text { Sexually active } & 3 \text { of } 6(50 \%) & 4 \text { of } 6(66.7 \%) & 4 \text { of } 6(66.7 \%) \\ \text { Erection } & 31.4(5.10) & 27.3(4.83) & 22.9(4.71)\end{array}$

*values are mean (SD), SD: Standard deviation

Table 3. Anal manometry results

\begin{tabular}{|c|c|c|c|c|c|c|c|c|}
\hline Patient & $\begin{array}{l}\text { Maximum } \\
\text { resting } \\
\text { pressure } \\
(\mathrm{mmHg})\end{array}$ & $\begin{array}{l}\text { Maximum } \\
\text { squeeze } \\
\text { pressure } \\
(\mathrm{mmHg})\end{array}$ & $\begin{array}{l}\text { First } \\
\text { sensation } \\
\text { (cc) }\end{array}$ & $\begin{array}{l}\text { Desire to } \\
\text { defecate } \\
\text { (cc) }\end{array}$ & $\begin{array}{l}\text { Maximal } \\
\text { tolerable } \\
\text { volume } \\
\text { (cc) }\end{array}$ & $\begin{array}{l}\text { Rectoanal } \\
\text { inhibitor } \\
\text { reflex } \\
(+/-)\end{array}$ & $\begin{array}{l}\text { Maximal } \\
\text { squeeze } \\
\text { time } \\
\text { (sec) }\end{array}$ & Comment \\
\hline 1 & 55 & 83 & 55 & 55 & 55 & $(-)$ & $>45$ & $\begin{array}{l}\text { EAS dysfunction, } \\
\text { sphincter } \\
\text { damage }\end{array}$ \\
\hline 2 & 39 & 137 & 10 & 50 & $>150$ & $(+)$ & $>45$ & IAS dysfunction \\
\hline 3 & 33 & 111 & 20 & 100 & $>150$ & $(+)$ & $>45$ & $\begin{array}{l}\text { IAS dysfunction, } \\
\text { sphincter } \\
\text { damage }\end{array}$ \\
\hline 4 & 45 & 105 & 30 & 80 & 160 & $(-)$ & $>45$ & Normal \\
\hline 5 & 50 & 110 & 20 & 60 & $>150$ & $(+)$ & $>45$ & Normal \\
\hline 6 & 60 & 120 & 30 & 90 & $>160$ & $(+)$ & $>45$ & Normal \\
\hline 7 & 65 & 140 & 15 & 75 & $>150$ & $(+)$ & $>45$ & Normal \\
\hline
\end{tabular}

EAS: External anal sphincter, IAS: Internal anal sphincter 
Table 4. Defecography results

\begin{tabular}{|c|c|c|c|c|c|c|c|c|}
\hline Patient & $\begin{array}{l}\text { Filling } \\
\text { Defect } \\
(+/-)\end{array}$ & $\begin{array}{l}\text { Sensation of } \\
\text { fullness } \\
(+/-)\end{array}$ & $\begin{array}{l}\text { Resting } \\
\text { coloanal } \\
\text { angles }\end{array}$ & $\begin{array}{l}\text { Flattening } \\
\text { coloanal angle } \\
\text { during } \\
\text { strainingz (+/-) }\end{array}$ & $\begin{array}{l}\text { Pelvic floor } \\
\text { descent during } \\
\text { straining } \\
(+/-)\end{array}$ & $\begin{array}{l}\text { Barium leak } \\
\text { sign during } \\
\text { straining } \\
(+/-)\end{array}$ & $\begin{array}{l}\text { Anorectal } \\
\text { expulsion } \\
\text { disorder } \\
(+/-)\end{array}$ & Comment \\
\hline 1 & $(-)$ & $(-)$ & Normal & $(-)$ & $(+)$ & $(+)$ & $(-)$ & $\begin{array}{l}\text { Fecal } \\
\text { incontinence }\end{array}$ \\
\hline 2 & $(-)$ & $(-)$ & Normal & $(-)$ & $(+)$ & $(+)$ & $(-)$ & $\begin{array}{l}\text { Fecal } \\
\text { incontinence }\end{array}$ \\
\hline 3 & $(-)$ & $(-)$ & Normal & $(-)$ & $(+)$ & $(+)$ & $(-)$ & $\begin{array}{l}\text { Fecal } \\
\text { incontinence }\end{array}$ \\
\hline 4 & $(-)$ & $(-)$ & Normal & $(-)$ & $(+)$ & $(-)$ & $(+)$ & $\begin{array}{l}\text { Obstuctif } \\
\text { defecation }\end{array}$ \\
\hline 5 & $(-)$ & $(-)$ & Normal & $(-)$ & (+) & $(-)$ & $(+)$ & $\begin{array}{l}\text { Obstuctif } \\
\text { defecation }\end{array}$ \\
\hline 6 & $(-)$ & $(-)$ & Normal & $(-)$ & $(+)$ & $(-)$ & $(-)$ & Normal \\
\hline 7 & $(-)$ & $(-)$ & Normal & $(-)$ & $(+)$ & $(-)$ & $(-)$ & Normal \\
\hline
\end{tabular}

fecal incontinence. After 1 year, $15 \%$ of the patients had frequent fecal incontinence, but after 2 years $90 \%$ had good gas and stool continence.

\section{Discussion}

In recent years, TME after neoadjuvant CRT has become the gold standard treatment for middle and lower rectal cancers. However, the major problem in colo-anal anastomosis is the risk of anastomotic leakage. T-C, which was first described by Turnbull and Cutait, attempts to reduce the morbidity associated with colorectal anastomosis., ${ }^{1,2}$

In $\mathrm{T}-\mathrm{C}$, there are differences in practice regarding whether the colonic stump tip is left open or closed, how long it should be waited between the stages and how the patient will be fed during this period. ${ }^{5}$ In our series, to prevent contamination and the mucous discharge would make it difficult to maintain the colonic stump during the waiting period and the possibility of the colonic motility could negatively affect adhesion, we closed the exteriosed colon end with stapler. The average waiting time between stages was 6 days. During this period, the patients were not fed orally in order to prevent colonic gas formation and bowel movements and total parenteral nutrition was applied.

In a recent meta-analysis of 45 randomized-controlled trials and 53 prospective cohort studies of complications following rectal resection for cancer, it was reported that the rates of anastomotic leak and pelvic sepsis were 11\% and $12 \%$, respectively. ${ }^{8}$ In a study by Eriksen et al. ${ }^{9}$ of 1958 patients who underwent resection for rectal cancer: $11.6 \%$ of total anastomotic leakage was detected. There were signifcantly higher rates of leakage in low anastomoses: $15.6 \%$ in anastomoses $3 \mathrm{~cm}$ and below, $13.7 \%$ in $4-6 \mathrm{~cm}$, $7.6 \%$ in $7-9 \mathrm{~cm}$ and $4.8 \%$ in $10 \mathrm{~cm}$ and higher ( $\mathrm{p}<0.001$ ). The presence of diverting ileostomy not only deteriorates the quality of life and poses difficulties in stoma care, but also its reversal requires another operation with $17 \%$ surgeryrelated morbidity and $0.4 \%$ mortality. ${ }^{5,10}$ Despite diverting ileostomy, in the literatüre ${ }^{8}$, the rate of anastomotic leakage was reported between 3 and 20\%. Furthermore, not all temporary stomas were reversed, and 3 to $25 \%$ of these stomas became permanent. ${ }^{11}$ In a systematic review by Hallet et al. ${ }^{12}$, seven studies including 1,124 patients were evaluated and the T-C was associated with a low rate of anastomotic leakage, pelvic morbidity, and without using stoma which are among the main advantages of this technique. Anastomotic leakage increases local recurrence ${ }^{4,12,13}$ and found to be an independent prognostic factor for local recurrence ${ }^{14}$ therefore, decreasing anastomotic leak rates could even result in a positive effect on T-C. Anastomotic leakage and local recurrence were not observed in our study. Pelvic abscess developed in one patient on the $16^{\text {th }}$ postoperative day, antibiotic treatment was sufficient and no additional intervention was required. Current studies ${ }^{4,15}$ have reported $67.5 \%$ OS. In our series, 5 -year OS $85 \%$ was found to be similar to the literature.

Some patients develop severe pelvic dysfunction following a sphincter-preserving resection of the rectum. Studies have shown that up to 25 to $50 \%$ of all patients experience major dysfunction on a daily basis with a significant impact on quality of life. ${ }^{16,17}$ The number of studies on functional outcomes after T-C is limited in the literature. It has been 
reported that the functional outcomes may have been worse after neoadjuvant radiotherapy. ${ }^{16,18}$ In a 85 patient series of Sage et al. ${ }^{19}$ whom underwent T-C consecutively $71 \%$ good and very good functional outcome (Wexner score between $0-10), 29 \%$ poor functional outcome was reported. In our series, the por results in early stages showed improvement in time. In postoperative follow up mean Wexner scores were 11,5 in 6 months (SD 2.7), 9.0 in 1 year (SD 2.12) and 7.2 in 2 years (SD 2.32). In the second year $90 \%$ patients are considered to have good functional outcome. In the postoperative $6^{\text {th }}$ month, defecography and anal manometry were performed on 7 patients; Three patients showed signs of impaired continence. No patient required a colostomy for major incontinence.

Lange and Van der Velde ${ }^{20}$ reported that postoperative incontinence after TME occurred due to intraoperative injuries to the innervation of the levator ani. Therefore, this functional result appears to be independent of reconstruction. Autonomic nerve-preservation is, therefore, essential for preserving the sexual and bladder function and this situation may not be related to the reconstruction technique, but related to the surgical technique. Our series sexual and bladder functions were found to be similar to the previous studies. ${ }^{1,2,3}$

In previous reports ${ }^{4,5,21}$, permanent stoma was needed in 1 to $6 \%$ of patients following T-C, however, Remzi et al. ${ }^{3}$ reported a rate of $25 \%$ in their study. In a series of 24 patients of Maggiorin ${ }^{22}, 2$ patients ( $8 \%$ ) required stoma due to poor functional outcome. In our series, a permanent stoma was opened in 2 male patients (15\%) due to ongoing fragmentation and evacuation problem at the end of the first year, and balloon dilatation was required in one patient due to anastomosis stenosis. Permanent stoma was performed because of the overreaction of the patients to evacuation and fragmentation. Given that functional results gradually are improving if patients could tolerate, permanent stoma could be avoided. We think that functional results are worse in male patients with high BMI and narrow pelvis.

The use of T-C depends on the surgeon's preferences according to the conditions and operations. Remzi et al. ${ }^{3}$ recommended $\mathrm{T}-\mathrm{C}$ as the appropriate procedure to use before creating a permanent stoma. Jarry et al. ${ }^{4}$ advocated its use as a routine procedure in middle and low rectal cancer. Nonetheless, there are some limitations to this study. First, the number of sample size is small $(n=13)$. Second, its retrospective design led us to interpret the results with caution. Another limitation is the lack of a comparison group. On the other hand, this study is among the limited reported studies evaluating the functional outcomes in long duraiton.
In the standard treatment of rectal cancer is TME after neoadjuvant CRT. Total neoadjuvant therapy and the subsequent wait and see approach, which has recently become increasingly popular in early stage rectal cancer, provides patients with a higher quality of life beyond dispute. ${ }^{23} \mathrm{We}$ think that it is necessary to personalize the treatment of rectal cancer by offering the most optimal treatment according to the expectations and wishes of the patient.

\section{Conclusion}

In conclusion, despite the absence of high-grade evidences and advent of stapling devices and increasing experience with pelvic surgery, T-C with reasonable oncological and functional results can be safely used as a sphincterpreserving procedure in the treatment of patients with middle and distal rectal cancer.

We would like to emphasize that surgeons who are interested in rectum surgery should keep this method in mind which gives the patient the option of surgery without performing a stoma and they should feel obliged to extend their knowledge about this technique.

\section{Ethics}

Ethics Committee Approval: The study protocol was approved by the local ethics committee of our institution (date, November 21, 2019; no. ATADEK-2019-18/16).

Informed Consent: A written informed consent concerning the surgical risks was obtained from all patients.

Peer-review: Internally and externally peer reviewed.

\section{Authorship Contributions}

Surgical and Medical Practices: O.S.G., L.V.T., A.Z., Concept: O.S.G., A.Z., Design: O.S.G., A.Z., Data Collection or Processing: L.V.T., Literature Search: L.V.T., B.G., Writing: O.S.G., A.Z.

Conflict of Interest: No conflict of interest was declared by the authors.

Financial Disclosure: The authors declared that this study received no financial support.

\section{References}

1. Cutait DE, Figliolini FJ. A new method of colorectal anastomosis in abdominoperineal resection. Dis Colon Rectum 1961;4:335-342.

2. Turnbull RJ, Cuthbertson F. Abdominorectal pull-through resection for rectal cancer and for Hirschsprung's disease. Delayed posterior colorectal anastomosis. Cleve Clin Q 196;28:109-115.

3. Remzi FH, El Gazzaz G, Kiran RP, Kirat HT, Fazio VW. Outcomes following Turnbull-Cutait abdominoperineal pull-through compared with coloanal anastomosis. Br J Surg. 2009;96:424-429.

4. Jarry J, Faucheron L, Moreno W, CA Bellara, Evrard S. Delayed colo-anal anastomosis is an alternative to prophylactic diverting stoma after total mesorectal excision for middle and low rectal carcinomas. Eur Surg Oncol 2011;37:127-133. 
5. Bianco F, Belli A, De Franciscis S, Falato A, Romano GM . "Scarless" and no-stoma surgery for low rectal cancer: the laparoscopic pull-through delayed "high" colo-anal anastomosis. Updates Surg 2016;68:99-104.

6. Ware J Jr, Kosinski M, Keller SD. A 12-Item Short-Form Health Survey: construction of scales and preliminary tests of reliability and validity. Med Care 1996;34:220-233.

7. Jorge JM, Wexner SD. Etiology and management of fecal incontinence. Dis Colon Rectum 1993;36:77-97.

8. Paun BC, Cassie S, MacLean AR, Dixon E, Buie WD. Postoperative complications following surgery for rectal cancer. Ann Surg 2010;251:807818

9. Eriksen MT, Wibe A, Norstein J, Norwegian Rectal Cancer Group. Anastomotic leakage following routine mesorectal excision for rectal cancer in a national cohort of patients. Colorectal Dis 2005;7:51-57.

10. Chow A, Tilney HS, Paraskeva P, Jeyarajah S, Zacharakis E, Purkayastha S. The morbidity surrounding reversal of defunctioning ileostomies: a systematic review of 48 studies including 6,107 cases. Int J Colorectal Dis 2009;24:711-723.

11. Sier MF, van Gelder L, Ubbink DT, Bemelman WA, Oostenbroek RJ. Factors affecting timing of closure and non-reversal of temporary ileostomies. Int J Colorectal Dis 2015;30:1185-1192.

12. Hallet J, Milot H, Drolet S, Desrosiers E, Grégoire RC, Bouchard A. The clinical results of the Turnbull-Cutait delayed coloanal anastomosis: a systematic review. Tech Coloproctol 2014;18:579-590.

13. Branagan G, Finnis D. Wessex Colorectal Cancer Audit Working Group. Prognosis after anastomotic leakage in colorectal surgery. Dis Colon Rectum 2005;48:1021-1026.

14. Bell SW, Walker KG, Rickard MJ, Sinclair G, Dent OF, Chapuis PH, et al. Anastomotic leakage after curative anterior resection results in a higher prevalence of local recurrence. Br J Surg 2003;90:1261-1266.
15. Siegel RL, Miller KD, Fedewa SA, Ahnen DJ, Meester RGS, Barzi A, et al. (2017) Colorectal cancer statistics. CA Cancer J Clin 2017;67:177-193.

16. Emmertsen KJ, Yen-Ting Chen T, Laurberg S. Functional results after treatment for rectal cancer. J Coloproctol 2014;34:55-61.

17. Bregendahl S, Emmertsen KJ, Lous J, Laurberg S. Bowel dysfunction after low anterior resection with and without neoadjuvant therapy for rectal cancer: a population-based cross-sectional study. Colorectal Dis 2013;15:1130-1139.

18. Qin Q, Huang B, Cao W, Zhou J, Ma T, Zhou Z, et al. Bowel Dysfunctio After Low Anterior Resection With Neoadjuvant Chemoradiotherapy or Chemotherapy Alone for Rectal Cancer: A Cross-Sectional Study from China. Dis Colon Rectum 2017;60:697-705.

19. Sage PY, Trilling B, Waroquet PA, Voirin D, Girard E, Faucheron JL. Laparoscopic delayed coloanal anastomosis without diverting ileostomy for low rectal cancer surgery: 85 consecutive patients from a single institution. Tech Coloproctol 2018;22:511-518.

20. Lange MM, Van der Velde CJ. Faecal and urinary incontinence after multimodality treatment of rectal cancer. PLoS Med 2008;5:e202.

21. Olagne E, Baulieux J, de la Roche E, Adham M, Berthoux N, Bourdeix O, et al. Functional results of delayed coloanal anastomosis after preoperative radiotherapy for lower third rectal cancer. J Am Coll Surg 2000;191:643649 .

22. Maggiori L, Blanche J, Harnoy Y, Ferron M, Panis Y. Redo-surgery by transanal colonic pull-through for failed anastomosis associated with chronic pelvic sepsis or rectovaginal fistula. Int J Colorectal Dis 2015;30:543-548.

23. Habr-Gama A, Perez RO, Nadalin W, Sabbaga J, Ribeiro U Jr, Silva e Sousa $\mathrm{AH} \mathrm{Jr}$, et al. Operative versus nonoperative treatment for stage 0 distal rectal cancer following chemoradiation therapy: long-term results. Ann Surg 2004;240:711-717; discussion 717-718. 